\title{
Origin of samples of Cannabis sativa through insect fragments associated with compacted hemp drug in South America
}

\author{
Marcos Patrício Macedo ${ }^{1,2}$, Cecília Kosmann² \& José Roberto Pujol-Luz ${ }^{2}$
}

${ }^{1}$ Instituto de Pesquisa de DNA Forense, Bloco E, SAI, 70610-200 Brasília-DF, Brazil. marcos.patricio@gmail.com

2Departamento de Zoologia, Universidade de Brasília, 70910-900 Brasília-DF, Brazil. jrpujol@unb.br

\begin{abstract}
Origin of samples of Cannabis sativa through insect fragments associated with compacted hemp drug in South America. Insects associated with a seizure of Cannabis sativa L. may indicate the origin of the illicit drug. Nevertheless, no work regarding this subject has been previously published for South America. In the present investigation, seven kilograms of vegetal material (C. sativa) were inspected for insect fragments. Three species were identified and used to test the origin of the seizure of cannabis plant material: Euschistus heros (Fabricius, 1794), Thyanta perditor (Fabricius, 1794) (Heteroptera, Pentatomidae), and Cephalotes pusillus (Klug, 1824) (Hymenoptera, Formicidae). These insect species restricted the geographic origin of the drug to the Neotropical region, and their distribution patterns showed an overlap of the State of Mato Grosso (Brazil), Argentina, and Paraguay. Based on this information, two of the three major C. sativa growing areas in South America were excluded: (1) the Colombian territory and (2) northeastern Brazil.
\end{abstract}

KEYWORDS. Brazil; Drug traffic; Forensic Entomology; Marijuana.

Cannabis sativa $\mathrm{L}$. is the most consumed illicit drug in the world. The United Nations Office on Drugs and Organized Crime (UNODC) estimates that 200,000 to 641,000 hectares are used worldwide in outdoor cultivation of the plant. UNODC data points for two main areas of $C$. sativa production in South America: (a) Colombia and (b) Paraguay and Bolivia territories (UNODC 2008). Also, the northeast region of Brazil (especially the border between the states of Bahia and Pernambuco, known as Marijuana Polygon) figures as an important area of drug plantation, aiming to supply the Brazilian market for marijuana. Despite what is observed in other plant-derived drugs like cocaine and heroine, the South American production of cannabis is widespread, with production centers poorly defined (UNODC 2008, 2009, 2010).

Determining the origin of a shipment of an illicit drug is a crucial step towards the formulation of policies of repression of production and consumption of psychotropics. Government intervention is economically and socially less expensive if done directly in the sites of production of narcotics, allowing the concentration of the efforts of public officials and the removal of armed conflicts in large urban centers. Even so, Brazilian laws treat the crime of drug traffic as qualified in the situations where the traffic occurs among the states of the federation and, more severely, when there is evasion of borders. For this reason, the determination of the origin of the drug is of direct and single interest in each judicial case involving drug dealing.

A great number of authors reported reliable methods for identification of cannabis samples, with possible application in retrieving information about the site of origin (Baker 1980;
Crosby et al. 1986; Brower 1994; Jagadish et al. 1996; Linacre \& Thorpe 1998; Datwyler \& Weiblen 2006; Howard et al. 2008, 2009). Efforts to identify shipments of $C$. sativa through molecular profiles (Castro 2006; Mehmedic et al. 2010), as well as through isotropic ratios (Shibuya et al. 2006), have been conducted in Brazil; however, judiciary police agencies still do not have a standard operating procedure for this purpose. In 1986, Crosby et al. made use of entomological vestiges to identify the geographical origin of a shipment of C. sativa seized in New Zealand. Despite the promising results reported by the group, further efforts were not made in this area. For South America, no such study has been previously carried out.

Thus, the purpose of this study was to verify the feasibility of using fragments of entomological nature and their geographical distribution to identify the origin of shipments of C. sativa seized in central Brazil.

\section{MATERIAL AND METHODS}

We examined seven kilograms of pressed plant material (roots, stems, leaves and seeds). The examined material corresponded to two seizures of cannabis and was divided into eight lots, with masses ranging between 700 to $1,100 \mathrm{~g}$, exception made for a lot with three kilograms. Each lot consisted of a block of pressed plant material that was unpacked and placed on a pedestal inside a screen collector (a bowl was placed upside down inside a larger bowl). The material was submitted to an initial screening with the help of a $5 x$ magnifying glass with artificial lighting (Fig. 1). After the initial screening, a more accurate one was carried out with 


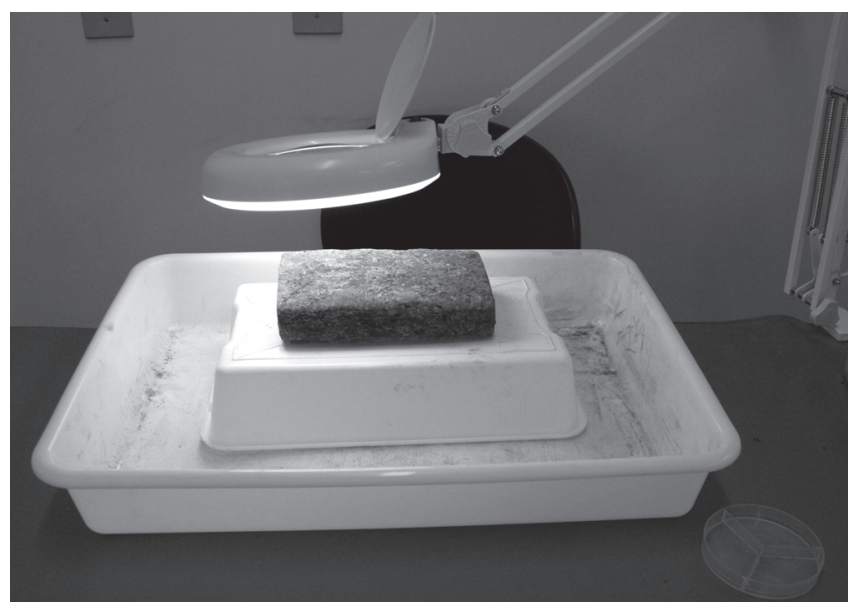

Fig. 1. Screening for insects in the cannabis plant material, showing the drug above the pedestal inside the screen collector under a $5 x$ magnifying glass with artificial lighting.

the aid of a stereoscopic microscope. Animal or other plant material removed from $C$. sativa block was isolated, photographed, registered, and received a reference number, being stored in individual microtubes. Insect samples that were considered identifiable were sent to expert taxonomists for species determination. All the fragments of insects found in the cannabis' survey were preserved as voucher material and deposited in the entomological collection of the Universidade de Brasília.

Putative contamination of the samples with insects from the place of screening of the material is discarded. Besides the fact that the screening was conducted in an environment free of large insects (a molecular laboratory of the judiciary police), all the marijuana examined was sealed and remained so from the moment of the seizure up to the screening. Moreover, all fragments were found between the layers of the lots and they were quite dry and damaged, in a condition which would not match with a possible contamination in the laboratory. Thus, we are convinced that the insects found were packaged together with the drug at the production site.

After the identification process, distribution maps for each of the involved species were produced based mainly on literature records and on specialists' reports. After that, the maps were overlapped, aiming to elucidate the traffic route of the seized material.

\section{RESULTS}

During the examination of the material, 52 entomological fragments were found, ranging from small pieces to whole insects. This represents an average of 7.4 entomological fragments per kilogram of examined material, or about five fragments per batch of $700 \mathrm{~g}$. From all samples, 32 fragments were identified at the order level. Of these, seventeen specimens could be identified only to this level, being two fragments classified as Lepidoptera (caterpillar exuviae), eight as Coleoptera, and seven as Hemiptera (Table I). Fifteen samples were identified to family level: thirteen fragments belonging to the family Pentatomidae (Hemiptera, Heteroptera), one to the family Cucujidae (Coleoptera), and the last one to the family Formicidae (Hymenoptera).

Table I. Identification of the fragments found on the pressed Cannabis sativa L. in a seizure in central Brazil.

\begin{tabular}{lll}
\hline \multicolumn{1}{c}{ Order } & \multicolumn{1}{c}{ Family } & \multicolumn{1}{c}{ Species } \\
\hline Hymenoptera (1) & Formicidae (1) & Cephalotes pusillus (1) \\
Coleoptera (9) & Cucujidae (1) & Not identified \\
Lepidoptera (2) & Not identified & Not identified \\
Hemiptera (20) & Pentatomidae (13) & Euschistus heros (6) \\
& & Thyanta perditor (1) \\
\hline Total: 32 & Total: 15 & Total: 8 \\
\hline
\end{tabular}

The number in parentheses indicates the number of fragments of the respective group found within the drug.

Eight fragments were identified to species level (Table I). Seven specimens of them were from the family Pentatomidae (Heteroptera): six (6) Euschistus heros (Fabricius, 1794) (Neotropical brown stink bug) (Fig. 2a), and one (1) Thyanta perditor (Fabricius, 1794) (Neotropical red-shouldered stink bug) (Fig. 2b). The last specimen was a gliding ant, Cephalotes pusillus (Klug, 1824) (Hymenoptera, Formicidae) (Fig. 2c).

Maps of distribution of the three identified species were made (Fig. 3a-c) and overlapped (Fig. 3d). Three regions have concomitant records of the three species: State of Mato Grosso (Brazil), Argentina, and Paraguay.

\section{DISCUSSION}

The post-harvest process of C. sativa for its storage, transportation and commercialization involves crushing and compacting the material. Since the insects can be crushed and compressed within the plant, their structure and diagnostic features can also be damaged. Thus, the process of isolating a specimen found in the cannabis is critical in order to preserve the morphological structure of the specimen for future identification.

The most frequent species, E. heros (six specimens), has a wide distribution in the Neotropical Region, with records from the States of Rio Grande do Sul, Santa Catarina and Paraná (southern Brazil) to Panama (Central America) (Panizzi \& Slansky 1985). Its presence was also recorded in the states of São Paulo (Panizzi \& Slansky 1985), Minas Gerais (southeastern Brazil) (Venzon et al. 1999), Mato Grosso do Sul (Panizzi \& Slansky 1985), Mato Grosso (Moreira et al. 2000), the Distrito Federal (midwest Brazil) (Medeiros et al. 1997), Acre (Thomazini 2001), Roraima, and Rondônia (northern Brazil) (Moreira et al. 2000). The species was almost absent in Brazil until the 1980s and it is currently the main pest of soybean, found in abundance from northern Paraná up to the central Brazil (Panizzi \& Slansky 1985). On September 2009, the species was recorded for the 

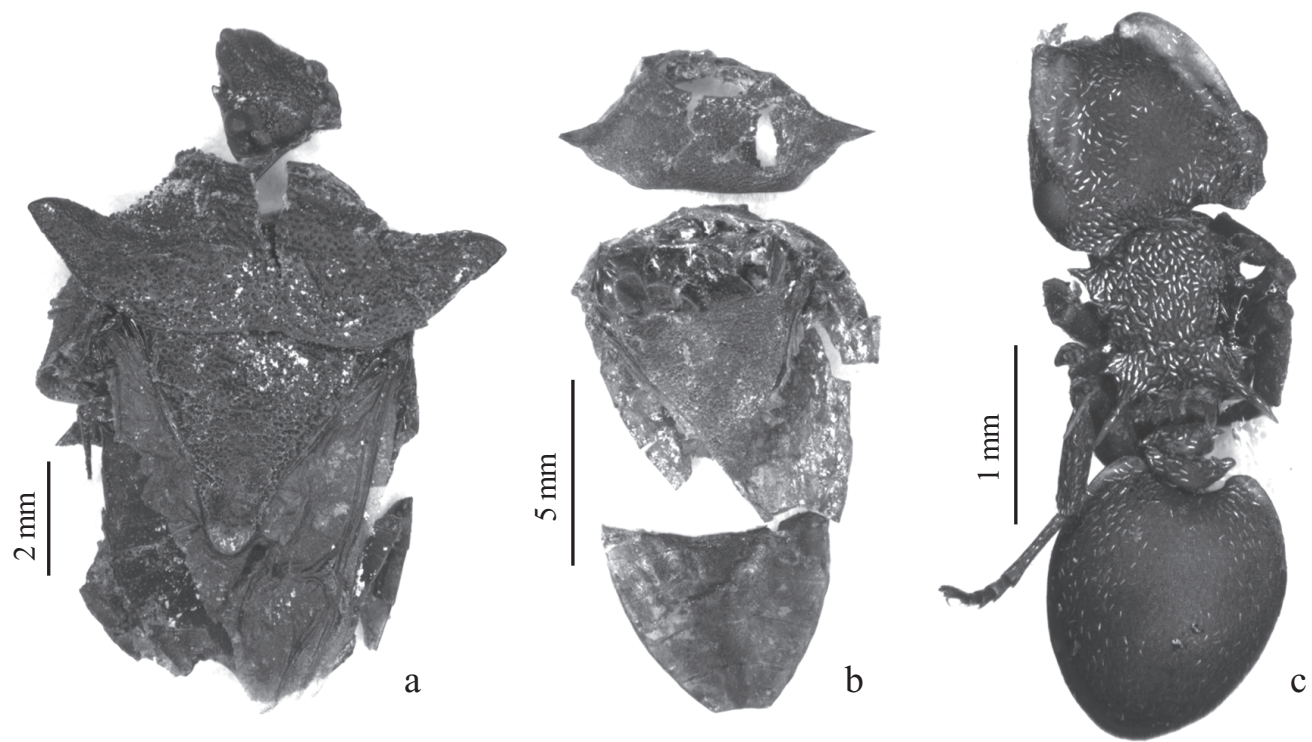

Fig. 2. Specimens found in the cannabis plant material: (a) Euschistus heros, (b) Thyanta perditor, and (c) Cephalotes pusillus.

first time in Argentina (Saluso et al. 2011, although in low numbers). In addition to published records on the occurrence of this stink bug, researchers say that this species is closely associated with extensive agriculture, potentially occurring in monocultures throughout the Neotropical Region (personal communication of Dr. Raúl Alberto Laumann, EmbrapaCenargen, and Dr. Jocélia Grazia, UFRGS).

The red-shouldered stink bug T. perditor is a pest well known in cultures of wheat, rice, sorghum (Panizzi 1997), and sunflower (Malaguido \& Panizzi 1998) in Brazil, and has been also recorded, although less frequently, as a soybean pest (Panizzi 1997). Yet, it is one of the main pests of soybean crops in Colombia (Corrêa-Ferreira \& Panizzi 1999). T. perditor has a wide distribution across the Neotropical Region (Hoffman-Campo 2000), being recorded in some states of the southeast and midwest Brazil (Busoli et al. 1994; Panizzi 1997; Malaguido \& Panizzi 1998) as well as additional states in southern, northern and northeastern Brasil (pers. comm., Dr. Jocélia Grazia). Despite the lack of documentation, researches affirm to have found T. perditor in other countries of South America, e.g. Argentina, Bolivia, Colombia, French Guyana, Paraguay, Suriname, Uruguay, and Venezuela (pers. comm. Dr. Jocélia Grazia).

The gliding ant $C$. pusillus has arboreal habits, showing a large distribution in the Neotropical Region. In Brazil, it was reported in two northern states, as well as in additional states in central, northeastern and southern Brazil. This species is also found in Argentina, Bolivia, Colombia, Costa Rica, Guyana, Paraguay, Peru, and Venezuela (Kempf 1951, 1958). While C. pusillus is not regarded as pest in agricultural areas, E. heros and $T$. perditor are species closely related to extensive monoculture and damage to crops (Panizzi \& Slansky 1985; Panizzi \& Vivan 1997).

It is the first time that these three species are recorded in association with $C$. sativa and their presence in the cannabis plant material restricts the geographical origin of the drug to the Neotropical Region. When the distributions of E. heros, T. perditor, and C. pusillus are superimposed, the region of overlap involves the State of Mato Grosso (Brazil), Argentina, and Paraguay (Fig. 3d). Based on this information, we can exclude two of the three major areas of cultivation of the drug in South America: (1) the Colombian territory and (2) northeastern Brazil.

In the study conducted by Crosby et al. (1986), the authors were able to identify to the specific level several specimens found in a cannabis seizure. Also, a large part of the identified specimens had a much more restricted geographic distribution than the ones of our study, what made possible a better determination of the original area of the drug by overlaying the geographic distribution of each species. As in the present study, the species found by Crosby et al. (1986) that showed a wide distribution were also pest species.

Another difference between the two studies is that, in the former one, the areas of production and seizure of the drug were located in different biogeographical regions, whereas in the present study the areas were in the same one (i.e., the Neotropical Region). There are significant differences between the entomofauna of Australasian and other regions (Turner et al. 2001). Thus, one would expect greater divergence of species among the areas cited in the New Zealand study.

Despite $C$. sativa being considered by the Brazilian government as containing four subspecies (or strains), some authors classify the genus Cannabis as having three $-C$. sativa, Cannabis indica, Cannabis ruderalis (Schultes et al. 1974; Hillig 2005), or four different species - the three already mentioned plus Cannabis afghanica (McPartland et al. 2000). The butterfly Pieris brassicae (Linnaeus, 1758) is able to differentiate between different cultivars of $C$. sativa (Rothschild \& Fairbarn 1980). Since there is no consensus on the number of species in the genus, as well as how many 

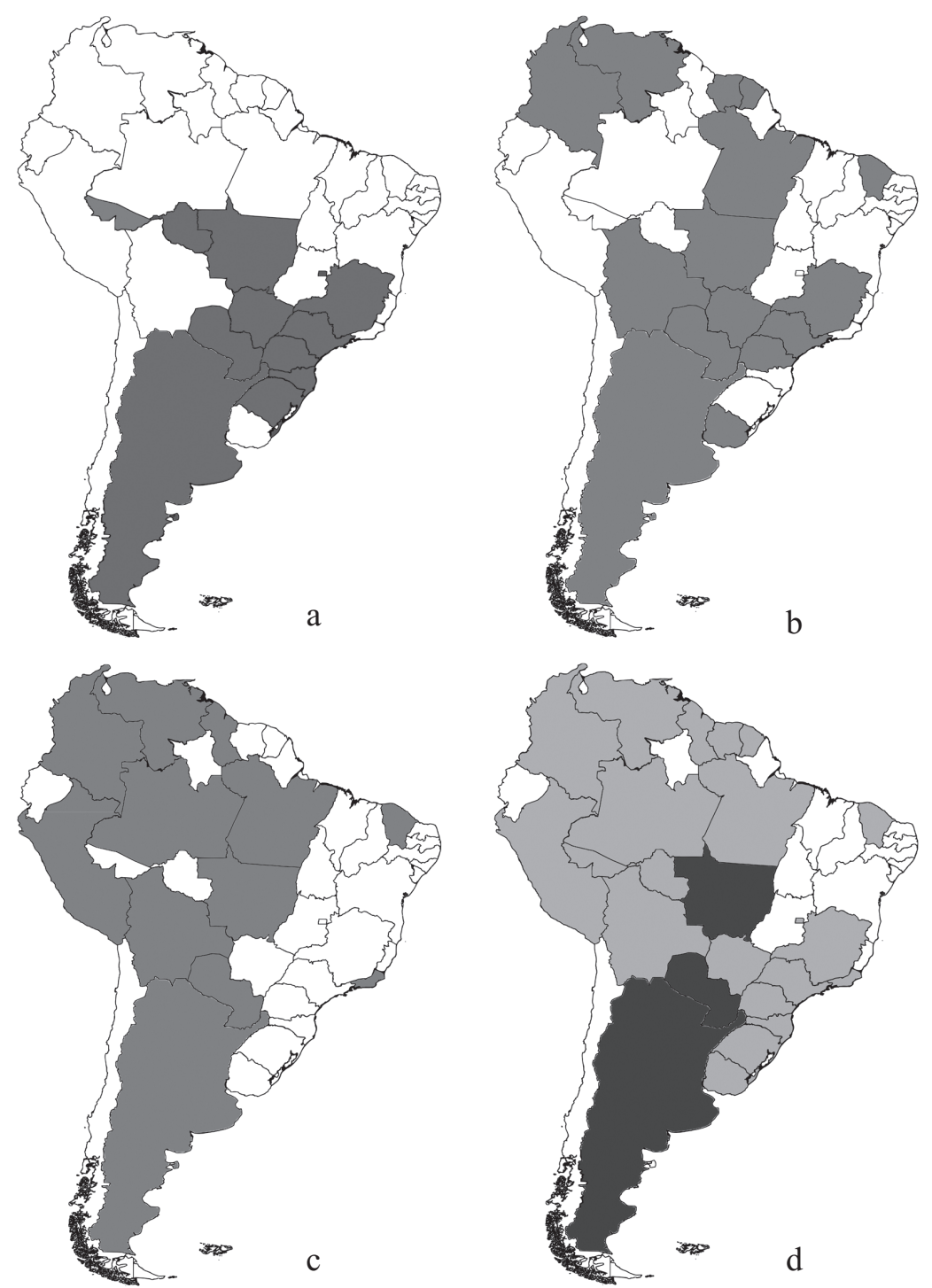

Fig. 3. Geographical distribution of (a) Euschistus heros; (b) Thyanta perditor; (c) Cephalotes pusillus; and (d) the three species combined. The black areas indicate the combined presence of the three species.

varieties are present in the examined seizure, the task of associating a particular insect to the plant gets even harder.

The technique examined here is time consuming and requires great experience of several taxonomists, which makes it hard to apply in a daily basis routine. The technique is valuable in the sense of providing reliable data through survey studies, so that the decisions to combat the drug traffic and the formulation of security policies may be taken in a more accurate way.

Finally, even if the insects found in the sample do not reveal the exactly geographical origin of the shipment, it is possible to, through the profile of insects found in two different seizures, to know if they were from the same region. An analysis of the insects found in marijuana seizures can also be quite useful in the sense that, although they have a very broad distribution, the composition of the entomofauna can serve as a signature of the drug original area. For the pursuit of these objectives, further studies are needed with larger amount of seized material from several geographical origins.

\section{ACKNOWLEDGEMENTS}

The authors thank M.Sc. Luciano Chaves Arantes (IDNAPCDF) for making this study viable in the local Police Department facilities. We are indebted to Dr. Marcos Antônio dos Santos Silva (UnB), Dr. Antonio José Mayhé Nunes (UFRRJ) and Dr. Jocélia Grazia (UFRGS) for their kindness and promptitude in identifying the insect samples. We are also grateful to Secretaria Nacional de Segurança Pública (SENASP/MJ), Polícia Civil do Distrito Federal (PCDF), Conselho Nacional de Desenvolvimento Científico e Tecnológico (CNPq), and Fundação de Apoio à Pesquisa do Distrito Federal (FAP-DF) for the grants and financial support. 


\section{REFERENCES}

Baker, P.B., Gough, T.A. \& Taylor, B.J. 1980. Illicitly imported cannabis products: some physical and chemical features indicative of their origin. Bulletin on Narcotics 32: 31-40.

Brower, A.V.Z. 1994. Rapid morphological radiation and convergence among races of the butterfly Heliconius erato inferred from patterns of mitochondrial DNA evolution. Proceedings of the National Academic of Sciences USA 91: 6491-6495.

Busoli, A.C., Lara, F.M., Grazia, J. \& Fernandes, O.A. 1984. Occurrence of Thyanta perditor (Fabricius, 1794) (Heteroptera, Pentatomidae) damaging sorghum crop in Jaboticabal, São Paulo, Brazil [Sorghum sp.]. Anais da Sociedade Entomológica do Brasil 13: 179-181.

Castro, J.L.O. 2006. Desempenho forense de microssatélites para a investigação da origem de Cannabis sativa no Brasil e Paraguai. M. Sc. thesis. Brasília, Universidade Católica de Brasília, 78 p.

Corrêa-Ferreira, B.S. \& Panizzi, A.R. 1999. Percevejos da soja e seu manejo. Londrina, EMBRAPA-CNPSo, 45 p.

Crosby, T.K., Watt, J.C., Kistemaker, A.C. \& Nelson, P.E. 1986. Entomological identification of the origin of imported cannabis. Journal of the Forensic Science Society 26: 35-44.

Datwyler, S.L. \& Weiblen, G.D. 2006. Genetic variation in hemp and marijuana (Cannabis sativa L.) according to amplified fragment length polymorphisms. Journal of Forensic Sciences 51: 371-375.

Hillig, K.W. 2005. Genetic evidence for speciation in Cannabis (Cannabaceae). Genetic Resources and Crop Evolution 52: 161-180.

Hoffmann-Campo, C.B., Moscardi, F., Corrêa-Ferreira, B.S., Oliveira, L.J., Sosa-Gómez, D.R., Panizzi, A.R., Corso, I.C., Gazzoni, D.L. \& Oliveira, E.B. 2000. Pragas da soja no Brasil e seu manejo integrado. Londrina, Embrapa Soja, 70 p.

Howard, C., Gilmore, S., Robertson, J. \& Peakall, R. 2008. Developmental validation of a Cannabis sativa STR multiplex system for forensic analysis. Journal of Forensic Sciences 53: 1061-1067.

Howard, C., Gilmore, S., Robertson, J. \& Peakall, R. 2009. Cannabis sativa STR genotype database for Australian seizures: forensic applications and limitations. Journal of Forensic Sciences 54: 556-563.

Jagadish, V., Robertson, J. \& Gibbs, A. 1996. RAPD analysis distinguishes Cannabis sativa samples from different sources. Forensic Science International 79: 113-121.

Kempf, W.W. 1951. A taxonomic study on the ant tribe Cephalotini (Hymenoptera: Formicidae). Revista de Entomologia 22: 1-244.

Kempf, W.W. 1958. New studies of the ant tribe Cephalotini (Hym. Formicidae). Studia Entomologica 1: 1-168.

Linacre, A. \& Thorpe, J. 1998. Detection and identification of cannabis by DNA. Forensic Science International 91: 71-76.

Malaguido, A.B. \& Panizzi, A.R. 1998. Pentatomofauna associated with sunflower in Northern Paraná State, Brazil. Anais da Sociedade Entomológica do Brasil 27: 473-475.
McPartland, J.M., Clarke, R.C. \& Watson, D.P. 2000. Hemp Diseases and Pests: Management and Biological Control. Cambridge, CABI, xvi+255 p.

Medeiros, M.A., Schimidt, F.V.G., Loiácono, M.S., Carvalho, V.F. \& Borges, M. 1997. Parasitismo e predação em ovos de Euschistus heros (Fab.) (Heteroptera: Pentatomidae) no Distrito Federal, Brasil. Anais da Sociedade Entomológica do Brasil 26: 397-401.

Mehmedic, Z., Chandra, S., Slade, D., Denham, H., Foster, S., Patel, A.S. Ross, S.A., Khan, I.A. \& ElSohly, M.A. 2010. Potency trends of $\Delta$-THC and other cannabinoids in confiscated cannabis preparations from 1993 to 2008. Journal of Forensic Sciences 55: 1209-1217.

Moreira, M.A.B., Gianluppi, D., Corrêa-Ferreira, B.S. \& Corso, I.C. 2000. Flutuação populacional de Nezara viridula (Heteroptera: Pentatomidae) na cultura da soja em Roraima. Reunião de Pesquisa de Soja da Região Central do Brasil 22: 63-64.

Panizzi, A.R. 1997. Wild hosts of pentatomids: ecological significance and role in their pest status on crops. Annual Review of Entomology 42: 99-122.

Panizzi, A.R. \& Slansky Jr., F. 1985. Review of phytophagous pentatomids (Hemiptera: Pentatomidae) associated with soybean in the Americas. Florida Entomologist 68: 184-214.

Rothschild, M. \& Fairbairn, J.W. 1980. Ovipositing butterfly (Pieris brassicae L.) distinguishes between aqueous extracts of two strains of Cannabis sativa L. and THC and CBD. Nature 286: 56-59.

Saluso, A., Xavier, L., Silva, F.A.C. \& Panizzi, A.R. 2011. An invasive pentatomid pest in Argentina: Neotropical Brown Stink Bug, Euschistus heros (F.) (Hemiptera: Pentatomidae). Neotropical Entomology 40: 704-705.

Schultes, R.E., Klein, W.E., Plowman, T. \& Lockwood, T.E. 1974. Cannabis: An example of taxonomic neglect, p. 21-38. In: Rubin, V. (Ed.). Cannabis and culture. Chicago, Mouton Publishers, v+598 p.

Shibuya, E.K., Sarkis, J.E.S., Neto, O.N., Moreira, M.Z. \& Victoria, R.L. 2006. Sourcing Brazilian marijuana by applying IRMS analysis to seized samples. Forensic Science International 160: 35-43.

Thomazini, M.J. 2001. Insetos associados à cultura de soja no Estado do Acre. Acta Amazonica 31: 673-681.

Turner, H., Hovenkamp, P. \& van Welzen, P.C. 2001. Biogeography of Southeast Asia and the West Pacific. Journal of Biogeography 28: $217-230$.

UNODC. 2008. World Drug Report 2008. Available at: http://www.unodc. org (accessed October 11, 2012).

UNODC. 2009. World Drug Report 2009: A Century of International Drug Control. Available at: http://www.unodc.org (accessed October 11, 2012).

UNODC. 2010. World Drug Report 2010. Available at: http://www.unodc. org (accessed October 11, 2012).

Venzon, M., Ferreira, J.A.M. \& Ripposati, J.G. 1999. Parasitism of stink bug eggs (Hemiptera: Pentatomidae) of soybean fields in the Triângulo Mineiro, Minas Gerais, Brazil. Revista de Biologia Tropical 47: 1007-1013. 